\title{
Embodying a Caring Science: An Ethnographic Analysis of the Communicative Practices of a Colombian Trans-Woman Scientist in the Media ${ }^{1}$
}

Tania Pérez-Bustos ${ }^{2}$

Universidad Nacional de Colombia, Bogotá, Colombia ${ }^{3}$

tpbustos@gmail.com

Recibido: 29 de junio de 2015

Aceptado: 3 de septiembre de 2015

Disponible en línea: 9 de mayo de 2016

\footnotetext{
This research paper was developed under the funding of a DAAD Research Fellowship at the LA Freie Universität Berlin 2013-2014. The paper analyzes the media coverage of a transwoman scientist in Colombia.

2 Phd in Education

3 Associate Professor, School of Gender Studies
} 


\title{
Embodying a Caring Science: An Ethnographic Analysis of the Communicative Practices of a Colombian Trans-Woman Scientist in the Media
}

\begin{abstract}
This paper analyzes the communicative practices of a Colombian trans-woman scientist, biologist Brigitte Baptiste, when she speaks publicly about environmental issues on different media platforms. In the analysis, I explore the implications of Baptiste's public presence for the imaginaries of readers and journalists regarding science, scientists, and trans-people in Colombia. Leaning on certain feminist critiques of science, I analyze communicative practices as matters of care. Throughout the analysis, I find that care in Baptiste's public presence is performed through the ways in which she connects biodiversity and sexual diversity, thinking with trans-women's experiences to transgress the borders of science and connect it to activism and public service. I conclude that Baptiste's public presence in Colombia is an exceptional example of gender diversity acceptance in the present, though it does represent a speculative commitment towards embracing diversity in general in the future.

Keywords: matters of care; public communication of science; diversity; trans-women scientists; Colombia

\section{La personificación de la ciencia del cuidado: análisis etnográfico de las prácticas comunicativas en los medios de una cientifica trans colombiana}

\section{Resumen}

Este trabajo analiza las prácticas comunicativas de una científica trans colombiana, la bióloga Brigitte Baptiste; centrándose de modo particular en aquellas en las que Baptiste habla en público sobre temas ambientales en diferentes plataformas mediáticas. En el análisis, se exploran las implicaciones de su presencia pública en los imaginarios de lectores y periodistas con respecto a la ciencia, las y los científicos y las personas trans en Colombia. Apoyándome en la crítica feminista de la ciencia, analizo las prácticas comunicativas de Baptiste como asuntos de cuidado. A lo largo del análisis, encuentro que el cuidado en la presencia pública de Baptiste se configura en las formas en que ella conecta la biodiversidad con la diversidad sexual, a través de un 'pensar con' las experiencias de otras mujeres trans y con ello transgredir las fronteras de la ciencia, conenctándola con el activismo y el servicio público. Concluyo que la presencia pública de Baptiste en Colombia es un ejemplo excepcional de aceptar la diversidad en el presente, aunque representa un compromiso especulativo de abrazar la diversidad en general en el futuro.

Palabras clave: asuntos de cuidado; comunicación pública de la ciencia; diversidad; científicas trans; Colombia

\section{A personificação da ciência do cuidado: análise etnográfica de práticas de comunicação nos meios de comunicação de um colombiano científica trans}

\section{Resumo}

Este trabalho analisa as práticas comunicativas de uma cientista trans colombiana, a bióloga Brigitte Baptiste, se centrando particularmente em aquelas em que Baptiste fala em público sobre questões ambientais nas diferentes plataformas mediáticas. Na análise, exploram-se as implicações da sua presença pública nos imaginários de leitores e jornalistas no que diz respeito da ciência, as e os científicos e o pessoal trans na Colômbia. Apoiando na crítica feminista da ciência, analiso as práticas comunicativas de Baptiste como assuntos de cuidado. Ao longo da análise, encontro que o cuidado na presença pública de Baptiste é configurado nas formas em que ela conecta a biodiversidade com a diversidade sexual, através de um 'pensar com' as experiências de outras mulheres trans e assim transgredir as fronteiras da ciência, conectando-a com o ativismo e o serviço público. Concluo que a presença pública de Baptiste na Colômbia é exemplo excepcional de aceite da diversidade no presente, ainda que represente um compromisso especulativo de abraçar a diversidade em geral no futuro. Palavras-chave: assuntos de cuidado; comunicação pública da ciência; diversidade 
In 2009, Maloka, an interactive science center in Bogotá, developed an exhibition on the history of science in Colombia. One of the exhibits was on the topic of diversity. The curators presented photographs of different people to confront cultural stereotypes that connect physical appearance with professions ${ }^{4}$. Brigitte Baptiste, a Colombian transwoman biologist, was one of those included in the exhibit.

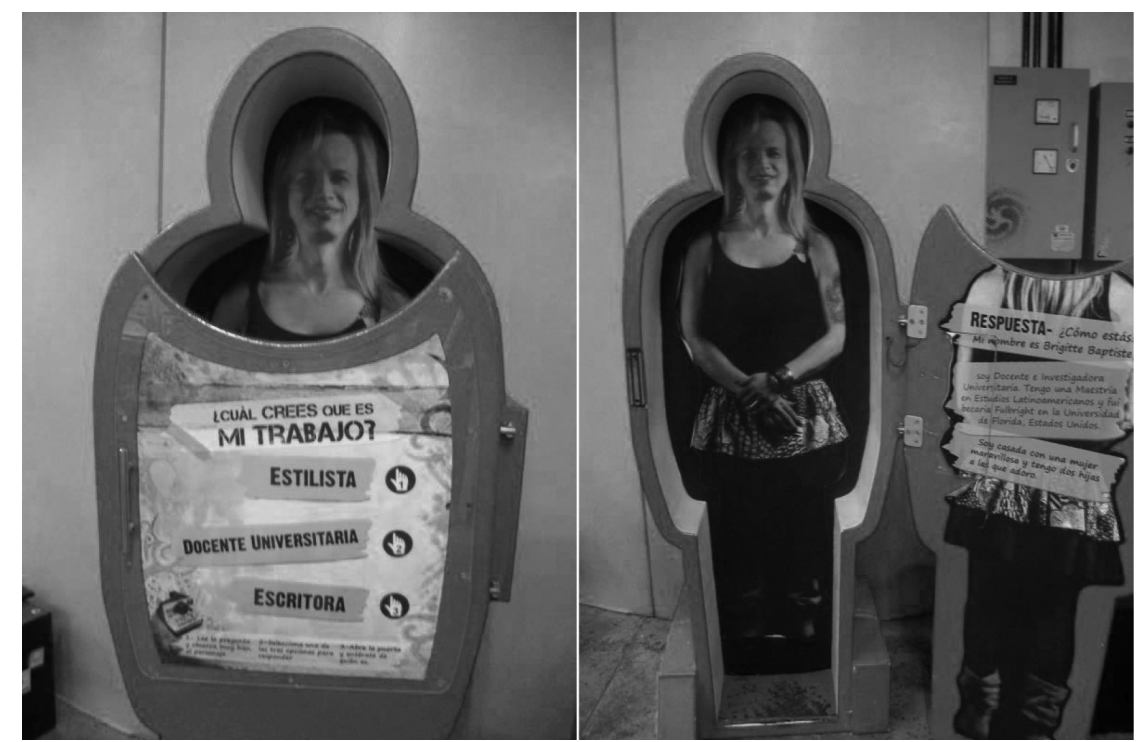

Image 1. Exhibit of Brigitte Baptiste on diversity in Maloka Interactive Science Center.

Source: Photo taken by Natalia Rodríguez Delgado, Maloka Marketing Coordinator.

When viewing Baptiste's photograph (see Image 1), visitors were presented with the following question: Who do you think I am? A. Hairdresser, B. University professor, C. Writer"5. A panel on the exhibit opened to reveal a life-size full body picture of Baptiste and the answer: 'I am a researcher and university professor. I have a Master's in Latin American Studies from the United States and was a Fulbright research

4 The exhibit was part of a larger section presenting the Chorographic Commission, a scientific project carried out in the Republic of New Granada (now Colombia) during the mid-nineteenth century, which aimed to map all of the New Granadian regions, and characterize the occupations, costumes and racial types of the inhabitants (González de Arenas, 2008).

5 All empirical data used for this paper are originally in Spanish. All translations are mine. 
fellow at the University of Florida, United States. I am married to a wonderful woman and have two daughters whom I adore." The exhibition curators expected that most visitors would answer A, since the majority of trans-women in Colombia are popularly known to work either as hairdressers or as sex workers (Colombia Diversa, 2010). Indeed, "People were surprised. How is she a scientist? She does not look like one" (Interview, exhibition curator).

This exhibition took place two years before Baptiste was appointed the director of the Alexander von Humboldt National Institute for Research on Biological Resources (from here on referred to as the Humboldt Institute). It was then that she became famous on a national scale. News about the appointment of a trans-woman scientist as director of this prestigious public research institute was all over the media. She was nominated person of the year in 2011 (Revista Credencial, 2011), presented as a trans-woman with a brilliant career in science. After the initial boom of the appointment passed, the media continued to refer to her as an expert source on environmental issues of different kinds, which gave her and the Humboldt Institute greater visibility. In 2012 and 2013, she started writing regular opinion articles in two newspapers -La República and La Silla Vacía-demonstrating a particular vision about nature-culture relations that, I argue, can be understood from the perspective of care in technoscience (Puig de la Bellacasa, 2010). ${ }^{7}$

Baptiste's presence in the media is interesting to analyze for various reasons. First of all, she poses a question about gender diversity in the production of scientific knowledge in a context where this has not been widely discussed. Studies on the Ibero-American region have emphasized the absence of women in certain areas of science and in decision-making roles within the scientific system (Vessuri \& Canino, 2006; Pérez Sedeño, 2011). Others have questioned how this imbalance has

6 In the original Spanish, Baptiste writes "Soy Docente e Investigadora Universitaria," which uses the feminine case and implies that the speaker, Baptiste, is a woman.

7 As will be shown in the next section, this concept of care in technoscience is nurtured by reflections of care as work in feminist studies, but also goes beyond it, understanding care as an ethos, an ethical and political practice that is potentially present in knowledge production. I have reflected upon this in the following papers (Pérez-Bustos \& Botero Marulanda, 2014; Pérez-Bustos \& Botero Marulanda 2013; Pérez-Bustos \& García Becerra 2013). 
shaped science practices as androcentric, leaving feminine values out of the cultural shaping of the scientific ethos (Maffia, 2007). In these studies, research approaches converge on a discussion of the demographic bias that composes the scientific field and affects the democratization of knowledge in general. However, diversity is reduced to a male-female binary opposition, and the complexities that shape men and women scientists' identities are overlooked or simplified. In this context, Baptiste's public presence becomes somehow noisy, challenging this binarity. This particular noise that she embodies justifies, in analytical terms, her selection as a case study. Rather than implying that her gender position is an essentialist example of what she represents, to select her is an entry point for delving into how science and gender imaginaries are co-constitutive in a context such as Colombia. ${ }^{8}$ Having said that, one of the main questions that guides this study regards what she tells us about public understandings of gender and science, and those who do science in Colombia.

Another interesting issue that Baptiste's media presence allows us to analyze is precisely the role that her presence plays in shaping popular comprehensions of scientists. She is working in a context where scientific issues are usually absent in the popular media (Arboleda Castrillón, Hermelín Bravo \& Pérez-Bustos, 2011; Díaz del Castillo, Olarte Sierra \& Pérez-Bustos, 2012), and where scientists who popularize knowledge, or who hold public servant positions, are not seen as ideal scientists (Horst 2013; Johnson, Ecklund \& Lincoln, 2013). Science communication and management activities are positioned as subordinate in relation to science itself; something undertaken by other professionals to promote and make visible expert knowledge produced by scientists (Pérez-Bustos, 2014a). By contrast, Baptiste is a scientist who frequently uses media platforms to speak openly and carefully about environmental issues.

Lastly, Baptiste's public presence as a trans-woman scientist is interesting to analyze because it reminds us of the cultural stereotypes that Colombians have of trans-people: weird subjects found only in beauty parlors or whorehouses. This status directly affects their social

8 This situates this study as an example of the use of Feminist Standpoint Theory (Harding, 2004). 
mobility, and trans-people suffer discrimination in relation to health, education, and work rights (Secretaría Distrital de Planeación, 2010). With this in mind, we can think of Baptiste's public appearances in the media as caring practices, with the potential to publicly unmark trans-women's subordinate status and to place them, ambivalently, in a domain of privilege. ${ }^{9}$

Throughout this paper, I analyze Baptiste's communicative practices in the media as examples of matters of care in technoscience (Puig de la Bellacasa, 2011). I start the discussion by presenting some theoretical and methodological aspects that guide the study. This is followed by the presentation and discussion of the results, which I understand as an empirical appropriation of theory, as a mechanism to situate and with which to delve into concepts.

\section{Thinking with care: some theoretical and methodological clarifications}

Communicative practices interweave our perceptions and representations of science as a gendered space. To think about communicative practices through the lens of matters of care in technoscience implies, as I have argued elsewhere (Pérez-Bustos, 2014c), that they are acts of touching, through which we become with others. The idea of communication as touch, a practice with the potential to be caring, is inspired by the work of Maria Puig de la Bellacasa (2010; 2012; 2011; 2009). In the case of Baptiste's communicative practices, these acts are visible in the connections she knots between trans-women, humanity, and other species (Haraway, 2008), and in her presentation of science as a responsible endeavor (Singleton, 2011); that is, as a particular form of situated knowledge (Haraway; 1988). Here, I would like to highlight

9 In a previous paper, I presented and unfolded this hypothesis about Baptiste and her media appearances (Pérez-Bustos, 2014c). In this current paper, I delve into empirical data and discuss the limitations and implications of Baptiste's privileged position for trans-women in Colombia in general, and develop the linkage between, and the care dimensions of, biodiversity and sexual diversity, as she publicly poses them. 
two issues that frame this proposal relating to care in technoscience as both interdependence and as a utopian vision. ${ }^{10}$

Care as an ethos, beyond a form of work, is a way of being, of becoming with others, in a context of mutual dependence. It "implies reaching out to something other than the self" (Tronto, 1994, p. 103). Care is thus embedded in practices oriented towards shaping networks of interdependencies (Sevenhuijsen, 2003); it brings to the center of analysis marginalities, collectivities, bonds, and solidarities (Molinier, 2012). Besides this, the practice of caring is transformative, implying a particular way of relating to the future (Pérez-Bustos, Olarte Sierra \& Diaz del Castillo, 2014). I understand care as a speculative commitment oriented towards sustaining the vital in a broad sense (Fischer \& Tronto, 1990); indeed, it is somewhat utopian, since it allows us to think and act beyond our present concerns to imagine the future. In Puig de la Bellacasa's words, care as touching can be seen as "an invitation to re-think relationality and its corporeal character, as well as a desire for concrete, tangible, engagement with worldly transformation" $(2009$, p. 2)

Following feminist discussions of care in technoscience, this study aims to describe and reflect upon Baptiste's intentionally performed communicative practices related to her area of expertise. With this in mind, the interdependence, relationality, and speculative commitment that I have briefly described as central to matters of care in technoscience will be unfolded throughout the analysis itself as an example of how care can situate knowledge circulation in contexts marked by

\footnotetext{
10 Theoretical approaches to care in technoscience have been widely overlooked in Latin American studies of care. In this context, care has been predominantly understood as a subordinated and feminized form of labor performed by those in charge of maintaining the life of people in vulnerable conditions; this includes domestic and health care work, child and elderly care, as well as aesthetic and sexual labors. These studies have analyzed the neglected status of this work, in the public sphere in particular, as much as its gendered associated metaphors (i.e. Arango Gaviria \& Molinier 2011; Esquivel, Faur \& Jelin 2012; Pineda Duque, 2011). Thus, these perspectives have emphasized the economic, social, and cultural organization of the work of care, and the analysis therefore has the political potential to transform the realities of care laborers. However, as I have argued elsewhere (Pérez-Bustos, 2014b), this emphasis has subsumed the understanding of care as labor, which in turn has led to a failure to delve into the theoretical possibilities of this category in order to give an account of other caring practices. The analysis presented in this paper aims to contribute to the comprehension of care as present in technoscientific knowledge production and circulation, and so it understands care beyond a form of labor. Among other aspects, this paper emphasizes an understanding of the speculative nature of care and its interdependence and touching dimensions. These aspects are nurtured by a previous analysis of care in the narratives of forensic geneticists in Colombia (Pérez-Bustos et al., 2014).
} 
binaries in science and gender. This analysis is focused on communicative practices found on different online media platforms, from 2008 to $2012^{11}$. The timeframe was defined considering Baptiste's appointment as director of the Humboldt Institute in 2011; I wanted to trace her media presence before and after to analyze the relevance that the media has given to her gender performance as a trans-woman in relation to her performance as a scientist.

The research is based on an ethnographic content analysis of Baptiste's communicative practices in the aforementioned cultural products. Through these I sought to understand how the public presence of Baptiste on these platforms constitutes a particular practice of care in technoscientific knowledge circulation and, in particular, through which tactics and communicative mechanisms this is possible. As stated, I understand this as an analytical entry point to delve into the public communication of science in a particular context and not as an empirical assumption regarding Baptiste's gender positioning in relation to care. Thus the findings of this paper are more informative about what she represents to public imaginaries about science, scientists, and transgender people, than specifically about transgender scientists' positions and roles. This analysis is supported by twelve in-depth interviews: one with Baptiste, four with journalists and science communicators, two with selected colleagues of Baptiste at the Humboldt Institute, two with Colombian experts in the field of the environment, and three with trans-people activists. The preliminary findings of this research were discussed with Baptiste.

11 I traced Baptiste's communicative practices on various platforms: two online newspapers (eltiempo. com, elespectador.com), two economic and financial newspapers (larepublica.com, portafolio.com), two regional online newspapers (elcolombiano.com, lapatria.com), six online cultural magazines with national circulation (www.semana.com, www.credencial.com, www.diners.com, www.soho. com, www.revistadonjuan.com, www.cromos.com), and three independent newspaper blogs (lasillavacia.com, sentiido.com, lasnotasdepastor.com). Events in cultural institutions such as science museums, regional book fairs, and public policy meetings were also investigated; these included videos streamed via the internet. The search was principally for material in which Baptiste's voice was central. A total of ninety-two records were identified: thirty-one videos, fifty-one newspaper articles, and ten articles in cultural magazines. Given that this material circulates in virtual platforms, the analysis included the comments and responses of readers and viewers, which provided information about the perceptions that people have of Baptiste's points of view, and how they are shaped by her gender position and public image. The collection and systematization of information was conducted with the assistance of Sara Márquez-Gutiérrez. 


\section{Public presence and caring practices}

In the following three sections, I begin by introducing Baptiste's media presence, both as a trans-woman and as a scientist. This includes the transitions and tensions that the media have established between these two identities, as well as the contradictions that she poses regarding the representation of other trans-women in the media. In the second section, I present Baptiste's understandings of care in technoscience in terms of biodiversity, through the intimate connections she weaves between ecological science and public environmental management. I am interested here in providing an account of some of the symbolic bonds attached to her understandings of the environment and the situation of trans-women in Colombia. Lastly, I unfold the idea of how Baptiste explicitly talks about embodying the very biodiversity that she argues we must care for, and I explore the linkages and limitations that such a stance poses with regard to perceptions of nature-culture relationships and negotiations.

\section{Baptiste: a trans-woman and a scientist}

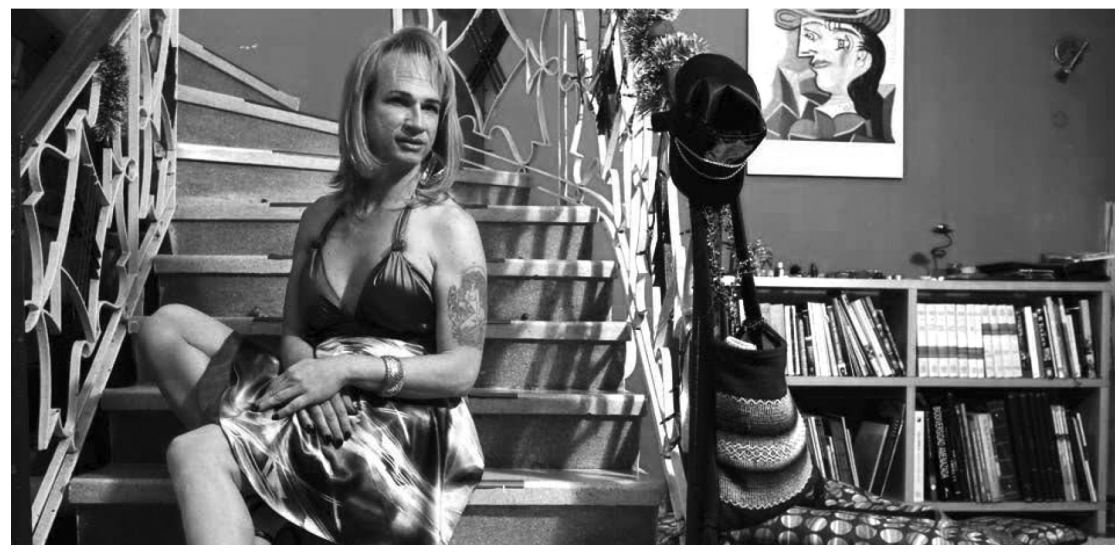

Image 2. Main picture used as a heading for an article published in the magazine Don Juan. Photographer: Sebastián Jaramillo

Source: López González (2010). 
In the investigated media sources, Baptiste is initially presented as a university professor with an undefined identity: a transvestite, a trans-sexual, a man with weird tastes, a man with a wife and kids, a homosexual, a woman who does not look like one, etc. There is, of course, abundant confusion over how to refer to her, a common issue in Colombian media references to trans-women (Guarín López \& Roa Polanco, 2011), which can be seen as an example of transphobia (Bettcher, 2014). Nevertheless, when Baptiste began to be present in the media, her confusing, often heteronormatively shaped-identity, was always accompanied by references to her scientific merits and outstanding abilities. ${ }^{12}$

Over time, this "man called Brigitte" (Semana, 2010) became the female director of the Humboldt Institute, a successful and politically committed person with an ambitious plan for managing biodiversity in Colombia. She is "the presidenta [female president] of biodiversity" (Acosta, 2013), "the escudera [female squire] of the environment" (Virviescas Gómez, 2012). At the beginning, it was her weird presence that captured media attention; her eccentric dress sense - on occasion associated with sex work - and the perception of her as a trans-woman "who has faced no obstacles in life" (Correa, 2011). Once she began to speak about her views on the environment, however, her gender position stopped being the primary issue. In some news reports about Baptiste, one can find statements from colleagues or previous students, such as "within ten minutes of being with Brigitte, her appearance becomes secondary. She is a genius, she might go around naked and nobody would care” (López González, 2010), or that "the interesting biologist overshadowed the "weirdo" (Semana, 2010). Such positive references were also present in the comments

12 One could say that she is recognized as a scientist because she is also perceived publicly as a man in the private domain: he likes women, has a wife, is a father; all of these are attributes that the media associates with manhood, as something biologically given and related to heteronormative sexuality. Considering that science is popularly shaped as a masculine domain and so a gendered, segregated space (Westbrook \& Schilt, 2013) the umbrella term for social practices of placing others in gender categories. We draw on three case studies showcasing moments of conflict over who counts as a man and who counts as a woman: public debates over the expansion of transgender employment rights, policies determining eligibility of transgender people for competitive sports, and proposals to remove the genital surgery requirement for a change of sex marker on birth certificates. We show that criteria for determining gender differ across social spaces. Genderintegrated spaces are more likely to use identity-based criteria, while gender-segregated spaces, like the sexual spaces we have previously examined (Schilt \& Westbrook 2009), the fact that Baptiste does not completely look like a woman might guarantee her access to the scientific field. 
made by readers and in the interviews conducted with journalists and Baptiste's colleagues for this study.

Some readers do not accept this shift in focus, as evidenced by numerous negative reactions to stories about Baptiste. She is accused of not dressing appropriately - "What a PAYASO [male clown], going to work dressed as a whore! What credibility can someone like that have?" (Comment by reader in Gómez, 2011) - or as a scientist who loses credibility due to being a trans-person - "if this person has not defined his perverted sexual situation, how is he or she going to define the environmental state of the páramos?" (Comment by reader in Silva Herrera, 2011). In contrast, some readers focus on her quality as an expert and director of a public research institute, as a brave and exemplary person: "Neither gender status nor sexual identity define the scientific qualities of a person. It is defined by your educational background and your dedication to research" and "A better representative of biodiversity could not be found. This speaks well of the Humboldt Institute" (Comments by readers in Correa, 2011). The question that remains unanswered after Baptiste's transition from weirdness to brilliance, as co-constructed by journalists and readers -where "the powerful gesture of her intelligence" (Interview, science museum Social Communicator) overshadows her gender positioning in the public sphere- is how much it exemplifies the actual acceptance of diversity.

Thinking on the words of a reader:

[...] when a person defines his/her gender like Prof. Baptiste does, and it is seen as something normal because of her professional condition, I wonder, does the same happen for those with similar gender positions who do not have the knowledge or the financial means to gain social respect? (Comment by reader in López González, 2010)

This question is relevant considering how other trans-women are presented in the media. Following a report from a Colombian media observatory on gender and sexuality, transgender people, in particular trans-women, are predominantly associated with crime, either as victims or victimizers (Guarín López \& Roa Polanco, 2011). 
Many media stories focus on murdered trans-women sex workers, or trans-women as hairdressers or activists; others portray trans-women as thieves and aggressors towards non-trans-people. ${ }^{13}$

In this setting, the media has depicted Baptiste as an exemplary or different kind of trans-woman. She is viewed as an example of success to be followed, as if her presence showed trans-women that there are other possibilities beyond sex work and crime. As journalists and readers say, she is "a role model [...] she allows trans-women to wonder about the possibility of diversifying the livelihoods they have" (Interview, El Tiempo journalist, No. 1) and "A remarkable example showing that trans-women can develop their lives beyond beauty parlors and prostitution" (Comment by reader in López González, 2010).

In relation to such opinions, other trans-women involved in activism -and whose only contact with Baptiste has been through the media- think, somewhat ambivalently, that she is a privileged woman in terms of education and employment who does not define herself completely in terms of womanhood (she has a wife, not a husband, for example). This makes Baptiste not quite like them or part of the trans-people's rights movement. They say that "She lacks street" (Interview, trans-women activists \#1 and \#2), referring to the limited contact she has with the reality of trans-women whose only work option is prostitution. ${ }^{14}$

With this in mind, for other trans-women Baptiste's public presence is no more than an exceptional case of acceptance of a population more often marked by discrimination and transphobia. However, these perceptions have also their nuances. As one trans-woman activist said:

${ }^{13}$ Until 2014, all media stories focused on trans-women, and trans-men were not present in the Colombian media.

${ }^{14}$ Such statements highlight the need for homogeneity and the sometimes fixed identities that sustain certain social movements in Colombia (Flórez-Flórez, 2010). In this case, trans-women's movements are crosscut by heteronormative values that privilege trans-women who define themselves as women (among other things) because of their heterosexuality, but also by the 'street experience' given by sex work and marginality; two things for which Baptiste does not qualify. 
Some of us say 'Baptiste does not embody the reality of trans,' but who does embody it? She generates other understandings about us, about access to rights such as education. The problem is that this makes people conclude that lack of access is purely our choice - 'But if she could, why couldn't you?' - not a matter of social discrimination (Interview, trans-woman activist, No. 3).

The above quotes situate Baptiste's public presence within a domain of ambivalence. Her identity as a scientist gives trans-women the idea that privilege is possible. At the same time, privilege is seen as something that places her apart from the vulnerable and stigmatized reality of most trans-women. How does Baptiste deal with these perceptions? How does she position herself in relation to other trans-women? And how does she symbolically connect with their stories and touch them through her own positioning as a scientist? In the following section I delve into these questions, tracing Baptiste's dialogues and encounters with those whom she embodies, but who simultaneously seem incredibly distant from her. As mentioned, I see these encounters as examples of how care situates knowledge circulation in contexts marked by binaries in science and gender.

\section{We must care for our uncomfortable connections}

[...] for decades we've been trying to shake off the annoyance of diversity, the inconvenience of coexisting with so many things, beings and ideas [...] We can think that diversity is uncomfortable, but we could also see it as surprising, uncertain, and full of uncontrollable possibilities [...] If it was not for the complexity that combines people, microbes, plants, and animals, there would not be room for change, adaptation, evolution ... When we accept that we all are frogs, ferns, or Wayuus, ${ }^{15}$ we will find the bonds where difference is nourishing (Baptiste in El Tiempo, 2012).

\footnotetext{
${ }^{15}$ The Wayuu is an indigenous group living in northern Colombia.
} 
As previously said, care is an act of touching, of becoming with others. This implies that it is a practice that (responsibly) interweaves the vulnerability that connects us all as beings. As a practice, care is embodied in the way we think with others (Puig, de la Bellacasa 2012); it is performed by touch, but is not "reducible to the body itself" (Merleau-Ponty in Puig de la Bellacasa, 2009, p. 308). The effects and affects that arise from touch may be present in the symbolic associations shaped by public narratives. With this in mind, how does Baptiste produce these caring practices through the connections she can forge with her media presence?

When a trans-woman scientist occupying a public position was no longer news, Baptiste's presence in the media started to be an intentional endeavor that she assumed as a scientist and public servant with a political commitment towards environmental issues. Her views on biodiversity, land distribution, and the use of ecosystems are examples of strong appropriations of knowledge (Maldonado Castañeda \& De Greiff Acevedo, 2011; Franco-Avellaneda \& Von Linsingen, 2011), published through regular opinion columns in various newspapers and independent news blogs.

As an ecologist, Baptiste publicly presents a particular preoccupation with the fragility of life, though she simultaneously highlights its adaptability, connectedness, and diversity. For her, understanding the complex and dynamic equilibrium that sustains ecosystems implies the need to recognize that we are inseparable parts of them, which means fighting the discursive invention of nature as something distant from us, something not socially created (Baptiste, 2012). This understanding also transgresses the idea of the environment as something sacred that should be preserved untouched: "I am not a particularly conservationist person or a radical environmentalist. I think we should care for and protect, not preserve but use, learn, enjoy" (Baptiste in Ruiz Navarro, 2011).

The connections Baptiste poses between care, use, learning, and enjoyment have productive and welfare connotations. In the case of the páramos, for example, she argues for the importance of defining 
the borders of these protected areas in an interdependent way. This includes thinking with farmers - usually deemed invaders and environmental predators - about the agricultural livelihoods that they have and the ways in which they can adapt to the needs of the paramos; with tourists who take pleasure in being in touch with local communities and in the contemplation of frailejón plants ${ }^{16}$; with victims of floods caused by degradation of the páramos and co-related ecosystems; with water itself and its cycles, a resource usually forgotten in the risk management plans and interventions for so-called natural disasters; and also with mining and extractive business initiatives of different scales, which potentially threaten or control the dialogue between these different human and non-human actors.

For Baptiste, understanding ecology, and more specifically biodiversity, implies thinking with others, even with those with whom one does not agree or does not usually consider to have a voice. What she calls for is a creative politics of dissenting-within (Puig de la Bellacasa, 2012). This is particularly relevant in the case of agribusiness or mining energy companies, since:

[...] the phenomenon of 'green washing' has been reported globally when it clearly shows that it is part of misleading advertising. But it is more difficult to analyze it when it is part of production processes that promote conservation of resources, reduce ecological footprints or channel significant investment into ecological endeavors (Baptiste, 2011).

This position shapes Baptiste's role as director of the Humboldt Institute and has led her, for example, to negotiate with oil companies such as Ecopetrol to fund research to help comprehension of land use in the páramos and enhance public policies that recognize all uses as part of biodiversity. For activists and scientists dealing with the environment, these kinds of initiatives are somehow contradictory: how can Baptiste negotiate with those who are behind extraction in the páramos?' (Field notes, informal conversation with an environmental anthropologist, 2013). Baptiste defends her position as being highly

${ }^{16}$ Frailejon plants are endemic species from the páramos in the Andean region. 
responsive to biodiversity, a complex and fragile phenomenon that we need to embrace collectively. It is through mediation, even that which is seen as improper and uncomfortable, that we may guarantee the future of biodiversity, a future that we still have to imagine.

With this, Baptiste, the public servant, embodies hope and does so connecting demands from different sectors: "We have not yet assumed that ecological changes do not come from the sum of segregated autarkies [...] Collective action is required, mediated by research, informal institutions, the state, and the market" (Baptiste, 2013a). This way of speculatively dealing with the future, connecting those who might not otherwise connect and generating trust between them (Sevenhuijsen, 2003), and becoming responsible for those mediations and encounters (Interview, Baptiste), is Baptiste's way of taking care of biodiversity.

To embrace interdependencies is not always comfortable or easy. As Baptiste says in the quote cited at the beginning of this section, "people are uncomfortable with diversity," just as scientists are uneasy with those in the profession who play the role of public servants, and as activists are mistrustful of oil companies and of the 'ivory tower' in which research is produced. This unease, in Baptiste's case, points to the boundaries of the world that she inhabits, a place in which science and public policy are intertwined and oriented towards the vital needs of local ecosystems, which, in turn, are understood as scenarios interwoven by and giving shelter to human and non-human relationships. This world is a meeting point where accountability is the goal. It is shaped by "binding ways of producing grounded knowledges" (Banco de la República, 2011) that lead to action and help in decision making, and is a world in which the actors are always aware that uncertainty is a better option than control or self-sufficient heroism: "research shall never recommend a closed course of action. It defines and specifies levels and factors of risk towards possible decisions and interventions. It does not predict [...] Living in uncertainty, after all, is a way of understanding freedom" (Baptiste, 2013b).

In this encounter between environmental public management and accountable science (Singleton, 2011), Baptiste takes a distance from 
neutral knowledge as much as from radical environmental activism, in particular what she refers to as their paralyzing agendas:

We have reached a point where scientists deny climate change to attack public management that does not suit their agendas, and one where environmental innovation is questioned in order to question 'monster' corporations, using certain forms of environmentalism to merely serve ideological purposes (Baptiste, 2013c).

In these perceptions of the environment as something created by culture, in the uncomfortable and seemingly contradictory connections between corporations and environmental agendas, and between accountable public management, non-radical activism, and a caring science, Baptiste makes symbolic associations with her gender position as a trans-woman. She discusses, for instance, a particular imaginary about the environment as something that should remain pristine in order to be natural. Arguing that the environment is constructed, intervened in, and touched, and that it is through these contacts that the environment becomes, she also poses a symbolic connection to her gender position as a trans-woman; a constructed position, which becomes natural through different transitions and interventions (García Becerra, 2009).

We could also infer some symbolic connections with her gender position as a trans-woman and the way in which she, as a scientist, promotes the assemblage of diverse actors to care for the environment. In this case, it is the metaphorical comparison between extraction in the páramos and aesthetic surgery on trans-bodies. Both are perceived by conservative agendas as altering nature, something that we should preserve. But when the alterations of natural bodies create new bodies, how these interventions can and should be accountable for the lives and novel beings that emerge? This is one of the careful questions that Baptiste poses.

Furthermore, as Baptiste inhabits the borderlands of science through generating trust and interdependencies (Sevenhuijsen, 2003) with 'unusual' partners, she positions herself as a hopeful mediator with the capacity to heal tensions and foretell the future: 
I see myself as a mediator, which was curiously the role that many indigenous groups gave to transgender people. People with the function to help transition ideas, resolve conflicts, heal. I would love to represent this shamanic character; though it would be a very particular shamanism in the midst of research, activism, and bureaucracy (Interview, Baptiste). ${ }^{17}$

One could say that Baptiste presents here a romanticized native figure of a trans-person existing in an idealistic land free of discrimination (Towle \& Morgan, 2013). However, it can also be argued that, by speculatively recognizing the utopian spirit of symbolically bonding trans-identities and environmental management, she demonstrates not only that she recognizes the vulnerability that comes with her privilege, but also that she is trying to think from this position about her own biodiversity.

\section{Becoming with and thinking biodiversity from trans experiences}

My testimony has to serve for people to reflect upon intolerance [...] Essentially, my activism is my daily life; it is in the ability I constantly have to develop in order to free myself from my own fears (Baptise in López González, 2010).

When Baptiste uses her public presence as a trans-woman scientist to bring forward her caring views on the environment, she does so in dialogue and tension with what trans-women activists think of her. Baptiste recognizes the privilege she has, but thinks she can use it as a way to deconstruct the marginal place that Colombian society has culturally given to trans-women, as well as gender stereotypes in general. This is her personal revolution, one she embodies carefully.

${ }^{17}$ For information about the healer role given to transgender people in Native American cultures, see (Lang, 1998). 
The first explicit connection between these issues is her open statement about biodiversity and sexual diversity: "it is easier when biodiversity starts with oneself" (Baptiste in Gómez, 2011). In saying this, Baptiste refers to how biodiversity is directly related to sexual diversity. Supporting her argument with the work of Joan Roughgarden (2004), Baptiste has presented these connections in science talks on exhibitions about the legacy of Darwin, in public academic events about law, gender and diversity, as well as in interviews she has given to the media. One example she uses to connect with people's imaginations is the case of Nemo, the little clownfish in the Pixar movie: "Nemo is transgender, depending on the needs of the reef, the clownfish changes gender as I have done" (Baptiste in Gómez, 2011). For some colleagues, these connections make her arguments on ecology stronger and clearer for non-academics: "She is memorable because of her double condition, a trans and a good science popularizer; it makes people anchor differently to what she says" (Interview, Humboldt Institute researcher \#1). For many science journalists, however, it biases her position as an expert, inhibiting her from being neutral and objective about biodiversity as a scientific fact; a reality that must be disembodied to be perceived objectively ${ }^{18}$.

The distrust that embodying a concept such as biodiversity in the public arena rouses is another example of the fear that people hold about diversity in general: "People ask me, 'Why are there 1784 species of birds in Colombia? Would it not be sufficient with 500?' As if they were asking for less biodiversity. Some people feel uncomfortable with it. 'Less gender diversity please, less LGBTI, we are sick of it"' (Batiste, TEDxTalks, 2013).

In this context, what does Baptiste want to tell us when she states that it is easier when biodiversity starts with oneself? On the one hand, it means that for Baptiste it has been easier to respect her desire to embody the trans-person she is than to ignore it; a desire that comes from her search for a gender identity in permanent transition,

${ }^{18}$ This is similar to critiques of Roughgarden and her proposal regarding the role of non-reproductive sexual practices in evolution. Being a trans-woman biologist herself, Roughgarden has been accused by her colleagues of being biased by her own experience of exclusion when developing her theory of evolution in the natural world (Gewin, 2003). 
as well as from her own understanding of ecology. "In the process of studying ecology, I faced my own body ecology and my own frustrations as a person. That's when I decided to make the transition ... as a need to gain some inner consistency, to connect my body with what I was doing as a scientist" (Interview, Baptiste). When sharing this testimony, Baptiste speaks on behalf of those who do not have the right of public speech (Dow \& Condit, 2005), especially due to the social condemnation that their transition has implied for them. However, as a political statement, she also acknowledges that her decision was different from the decisions that other trans-women have to make. When answering a question on what would have happened to her if she had not been a successful professional, she replied:

It would be hard, because what I see in other trans-people who write to me is that nobody employs them, they are not allowed to dress the way they want, and express their femininity or masculinity [...] In my case the possibility exists because I did it when I had gained a position, when I had a network of people who supported me, which made my transformation seem secondary (Baptiste in Dueñas Villamil, 2011).

As argued above, this distant positioning is seen by trans-women as partially empowering for them, giving to their claims and demands a different visibility, and destabilizing stereotypes built on them. It is as if Baptiste's public presence allows them the denied right of having privilege:

People often associate trans-women with stupidity and say, if they are stupid, of course they have no other choice than to become whores or hairdressers, what else could they do?' Then I think that the trans-movement can find in Baptiste a way to question what has been perversely associated with us (Interview, trans-woman activist \#3).

Baptiste, thus, speculatively thinks with other trans-women to allow for the collective imagination of a different future, especially, future generations to come. This situates the care she embodies as a world-making practice and. in doing so, she helps to design other 
transgressions in our imagination, carefully repairing what we think about gender binaries and their associated symbols. As she says, she questions the trivial codes that divide humanity into two groups: "I am both woman and man" (TEDxTalks, 2013) and "I transit across genders. I'm a being in movement, it makes me feel free" (Semana, 2010). Even when, on certain occasions, people seem to demand her to be more masculine, decisive, dominant, competitive, or hierarchical because of her position as a scientific director of a research institute, she says that on these occasions her greatest achievement has been to bring forward the woman in her:

Where I really make a substantial transition is towards what is culturally considered feminine: intuitiveness, versatility, relationality, that which is explicitly affective and emotional [...] it has allowed me to be at the center of many networks simultaneously (Interview, Baptiste).

Being at the center, visible and not discriminated against because of her choices, indeed being accepted and admired, is what characterizes Baptiste's public presence as a trans-woman. As mentioned above, her stance ambiguously attributes a sense of care for those who occupy a space of invisibility and stigmatization; but she is also an example of a very careful transgression of what scientists should look like. On the one hand, it is her eccentric presence that displaces the image of scientists as modest subjects (Rhoton, 2011):

She breaks ground in the scientific world because she represents scientific integrity; but also that which science rejects: banality and triviality (Interview, environmental scientist, No. 2).

She not only demystifies trans, but also demystifies science, because women scientists will not look good wearing a miniskirt, or bright colors, or makeup; they have to masculinize to fit in (Interview, El Espectador journalist, No. 2).

On the other hand, there are her own views on science - as a hybrid practice crosscut by ambivalent activism and responsive public 
management, an embodied, sensorial knowledge that connects with the emotions - that encourage those who work with the environment to take more consideration of their senses in order to "change the way we relate to each other, to nonhuman and human beings" (Baptiste in Hawkins \& Ojeda, 2011). With this in mind, Baptiste highlights that there is a reason for trans-women's existence, namely to show us that we still have an embodied experience of knowledge to embrace: "We do not want to transfigure or be unnoticed or diluted in culture. We feel comfortable with our disharmony, we have no identity problem and we believe that the experience of the body can be imagined infinitely" (TEDxTalks, 2013).

Embodying that which is disturbing and inappropriate, both as a scientist and a trans-woman, makes Baptiste a monster, albeit a hopeful one (Haraway, 1992; Law, 1991); a being with the capacity to embrace difference in a non-dualistic manner and teach us to live with diversity without aiming to control it. This ability, however, is neither comfortable nor the product of mere privilege; it is a laborious, ambiguous, yet desirable achievement, and so deeply caring.

\section{Final remarks}

I began this paper by arguing for the need to question the binary assumptions that have shaped reflections about gender in science in Ibero-America. Certainly, Baptiste embodies a plea for diversity that helps to move forward such debates; to think with inappropriate and uncomfortable diversities and destabilize not just gender but also 'normal' science.

These transgressions are precarious and limited, though this does not necessarily imply less powerful. This is important to stress because such transgressions are entangled with heteronormative values that, on occasion, partially reproduce instead of challenge the androcentric thought embedded in dominant scientific practices. This is exemplified by what seems to be accepted in terms of Baptiste's public appearances 
in the media - namely her brave and noisy quirkiness, her privilege and intelligence - compared to what is not always included - namely her connectedness with vulnerability, uncertainty and fear - in other words her caring practices and their worlding potential.

Such normalized public perceptions portray Baptiste as an exceptional example of societal acceptance. This sometimes reinforces the marginal role that popular imaginaries give to trans-women, who are seen as disreputable because of their choices, not because of the gendered social structure that they inhabit. But such public perceptions also lead to speculative thinking and considerations of the emotional relationality embedded in scientific discourses, as embodied caring values that demerit objectivity and so have to be kept hidden.

Baptiste's values are anything but hidden. From her eccentric presence that reminds us of the awkward combination of whore and scientist, to her careful words about biodiversity as something that entangles heterogeneity and nature-culture arrangements, Baptiste's presence is a speculative commitment to neglected things (Puig de la Bellacasa, 2011). On the one hand, thinking with her, a different reality for trans-women in Colombia becomes imaginable-perhaps not for those who nowadays embody discrimination, but for the trans-women to come- as well as for other odd beings out there whose existence we still do not imagine. On the other hand, Baptiste's communicative practices are examples of care -accountability and responsiveness- in contentious dialogues between nature, public management, activism, and corporate interests; examples that are ambiguity incarnate and that may -as much as any utopian practices that embrace diversityinterweave interdependencies into caring scientific thinking.

\section{Acknowledgments}

I would like to offer my thanks to Brigitte Baptiste for her comments on a previous version of this paper; to Sara Marquez-Gutiérrez, my assistant during the research process that framed this and other papers on Baptiste's case; to Rocío Rueda Ortiz, María Puig de la Bellacasa, 
Diana Ojeda, Carlos del Cairo, and the two blind reviewers for their insightful reading of earlier versions of this paper; and to Zoe Goldstein for her impeccable editing.

\section{References}

Acosta, M. M. (2013). Desde que las niñas son rosadas y los niños azules, estamos jodidos. Sentiido.com. Retrieved from http://sentiido.com/desde-quelas-ninas-son-rosadas-y-los-ninos-azules-estamos-jodidos /

Arango, L. G. \& Molinier, P. (2011). El trabajo y la ética del cuidado. Medellin, Colombia: La Carreta Editores.

Arboleda, T., Bravo, D., \& Pérez-Bustos, T. (2011) La cobertura de la ciencia en los noticieros colombianos: del análisis de resultados a las reflexiones metodológicas para su investigación. Ensaio Pesquisa Em Educação Em Ciências 13(3), 151-66.

Banco de la República (2011) La niña y el impacto sobre la biodiversidad. Colombia: Banco de la República Retrieved from http://www.youtube.com/ watch?v=R6wW_YUIllA

Baptiste, B. L. G. (2011). Greenwashing. La silla vacia. Retrieved from http:// www.lasillavacia.com/elblogueo/blogverde/26465/greenwashing

Baptiste, B. L. G. (2012, August). La naturaleza es un invento de los hombres. Diners. Retrieved from http://www.revistadiners.com.co/articuloespecial. php?ide $=17 \&$ id $=165$.

Baptiste, B. L. G.(2013a). Ecologías de escala. La República. Retrieved from http://www.larepublica.co/ecologías-de-escala_42713

Baptiste, B. L. G. (2013b). Ecología profética. La República. Retrieved from http://www.larepublica.co/ecología-profética_43263 
Baptiste, B. L. G. (2013c). Nada se toca. La República. Retrieved from http:// www.larepublica.co/nada-se-toca_48941

Bettcher, T. M. (2014). Trapped in the wrong theory: Rethinking trans oppression and resistance. Signs: Journal of Women in Culture and Society, 39(2), 383-406.

Colombia Diversa (2010). Situación de derechos humanos de la población LGBT. informe alterno presentado al comité de derechos humanos de Naciones Unidas. Bogotá, Colombia: Colombia Diversa.

Correa, P. (2011, January 2). Mi condición no fue un obstáculo. El Espectador. Retrieved from http:/ /www.elespectador.com/impreso/vivir/articulo-243176mi-condicion-no-fue-un-obstaculo.

Díaz, A., Olarte, M., \& Pérez-Bustos, T. (2012). Testigos modestos y poblaciones invisibles en la cobertura de la genética humana en los medios de comunicación colombianos. Interface: Comunicação-Saude-Educação, 16(41), 451-68.

Dow, B. J., \& Condit, C. M. (2005). The state of the art in feminist scholarship in communication. Journal of Communication, 55(3), 448-478. http://dx.doi. org/ 10.1111/j.1460-2466.2005.tb02681.x

Dueñas, J. (2011, August). Brigitte Baptiste, 'rompí el molde de ser hombre.' Cromos. Retrieved from http://www.cromos.com.co/personajes/actualidad/ articulo-142233-brigitte-baptiste-rompi-el-molde-de-ser-hombre

El Tiempo. (2012, September 23). Esta es mi propuesta de paz. El Tiempo. Retrieved from http://www.eltiempo.com/archivo/documento/CMS-12245741

Esquivel, V., Faur, L., \& Jelin, E. (2012). Las lógicas del cuidado infantil. Entre las familias, el Estado y el mercado. Buenos Aires D.F.: IDES.

Fischer, B., \& Tronto, J. (1990). Toward a feminist theory of caring. In E. K. Abel \& M. K. Nelson (Eds.), Circles of care: Work and identity in women's lives (pp. 35-62). NY: State University of New York. 
Flórez-Flórez, J. (2010). Lecturas emergentes. decolonialidad y subjetividad en las teorías de movimientos sociales. Bogotá, Colombia: Pontificia Universidad Javeriana.

Franco-Avellaneda, M., \& Von Linsingen, I. (2011). Popularización de la ciencia y La tecnología en América Latina: Mirando la política científica en clave educativa. Revista Mexicana de Investigación Educativa, 16(51), 1253-1272.

García, A. (2009). Tacones, siliconas, hormonas y otras criticas al sistema sexo-género. Feminismos y experiencias de transexuales y travestis. Revista Colombiana de Antropología, 45(1), 119-146. Retrieved from http:/ /www.sci.unal. edu.co/scielo.php?script=sci_arttext\&pid=S0486-65252009000100006\&lng=e s\&nrm=iso\&tlng=es

Gewin, V. (2003). A plea for diversity. Nature, 422(6930), 368-69. http:/ /dx.doi. org/10.1038/422368a

Gómez, G. (2011, August 14). Brigitte: Todo un barón... Von Humboldt. El Espectador. Retrieved from http://www.elespectador.com/impreso/vivir/ articulo-291874-brigitte-todo-un-baron-von-humboldt

González, M. C. (2008). La comisión corográfica: Aporte interdisciplinario para el mundo. Biblioteca Nacional de Colombia: Exposiciones Virtuales. Retrieved from http://www.bibliotecanacional.gov.co/recursos_user/exposicionesvirtuales / comision_corografica/pdf/comision_corografica.pdf

Guarín, L., \& Roa, C. (2011). La diversidad en los medios 2008 - 2009. In Todos los deberes, pocos los derechos. Situación de derechos humanos de lesbianas, gay, bisexuales y transgeneristas en Colombia 2008 -2009 (pp. 117-130). Bogotá: Colombia Diversa.

Haraway, D. (1988). Situated knowledges: The science question in feminism and the privilege of partial perspective. Feminist Studies, 14(3), 575-599.

Haraway, D. (1992). The promises of monsters: A regenerative politics for inappropriate/d others. In C. N. Grossberg \& P. A. Treichler (Eds.). Cultural Studies (pp. 295-337). NY: Routledge. 
Haraway, D. (2008). When species meet. Minneapolis: University of Minnesota Press.

Harding, S. (2004). Introduction: Standpoint theory as a site of political, philosophic, and scientific debate. In The Feminist Standponit Theory Reader. Intellectual and Political Controversies (pp. 1-15). NY: Routledege.

Hawkins, R., \& Ojeda, D. (2011). Gender and environment: critical tradition and new challenges. Environment and Planning D: Society and Space, 29(2), 237-253. http://doi.org/10.1068/d16810

Horst, M. (2013). A field of expertise, the organization, or science itself? Scientists's perception of representing research in public communication. Science Communication, 35(6), 759-99. http://dx.doi.org/10.1177/ 1075547013487513

Johnson, D. R., Ecklund, E., \& Lincoln, A. E. (2013). Narratives of science outreach in elite contexts of academic science. Science Communication, $X X(X)$, 1-25. http://dx.doi.org/10.1177/1075547013499142

Lang, S. (1998). Men as women, women as men: Changing gender in native American cultures. Texas: University of Texas Press.

Law, J. (1991). Introduction: monsters, machines and sociotechnical relations. In A Sociology of monsters: Essays on power, technology and dommination (pp. 1-25). NY: Routledge.

López, A. (2010, February). El profesor de la Javeriana que se viste de mujer. Don Juan. Retrieved from http:/ / www.revistadonjuan.com/interes/el-profesorde-la-javeriana-que-se-viste-de-mujer/7298879

Maffia, D. (2007). Epistemología feminista: La subversión semiótica de las mujeres en la ciencia. Revista Venezolana de Estudios de La Mujer, 12(28), 63-98.

Maldonado, O. J., \& De Greiff, A. (2011). ‘Apropiación fuerte' del conocimiento: Una propuesta para construir políticas inclusivas de ciencia, tecnología e innovación en América Latina. In P. Kreimer \& A. Arellano (Eds.), Estudio Social de La Ciencia y La Tecnología Desde América Latina (pp. 209-263). Bogota, Colombia: Siglo del Hombre Editores. 
Molinier, P.(2012, marzo 1). El trabajo de cuidado y la subalternidad. Catedra Inaugural - Posgrados En Estudios de Género (pp. 40). Bogotá, Colombia: Universidad Nacional de Colombia.

Pérez, E. (2011). Mujeres y pioneras en las ciencias: Una mirada a la realidad Iberoamericana. Ciência, Tecnología E Gênero. Abordagens Iberoameicanos, UTPFR, 213-232.

Pérez-Bustos, T. (2014a). Feminización y pedagogias feministas: Museos Iinteractivos, ferias de ciencia y comunidades de Software Libre en el Sur Global. Bogotá, Colombia: Editorial Javeriana.

Pérez-Bustos, T. (2014b). El ethos del cuidado en la producción de conocimiento, una aproximación desde la antropología feminista al campo científico. In Deborah (Comp. \& Ed.). Coloquio Latinoamericano de Antropología Feminista (pp. 149-168). Buenos Aires, DF: Daich, Libreria.

Pérez-Bustos, T. (2014c). Of caring practices in public communication of science: seeing through trans-women scientists' experiences. Signs: Journal of Women in Culture and Society, 39(4), 857-866.

Pérez-Bustos, T., \& Botero, D. (2013). Entre el afuera y el adentro. La configuración del campo académico y sus fronteras desde las prácticas comunicativas de científicas negras en Colombia. Revista Co-Herencia, 10(18), 189-220.

Pérez-Bustos, T., \& Botero, D. (2014). Otras prácticas educomunicativas: Otras sexualidades, potencialmente otro. Revista de Estudios Sociales, 18(2013), 113-127.

Pérez-Bustos, T., \& García A. (2013). Situating women scientists with nonnormative gender positions in the Colombian National System of Science and Technology. Acta Colombiana de Psicología, 16(2), 1-21.

Pérez-Bustos, T., Olarte, M. F., \& Diaz, A. (2014). Working with care: experiences of invisible women scientists practicing forensic genetics in Colombia. In E. Medina, I. Marques \& C. Holmes (Eds.), Beyond Imported Magic: Studying Science and Technology in Latin America (in Press). Cambridge, MA: MIT Press. 
Pineda, J. (2011). La carga del trabajo de cuidado: Distribución social y negocación familiar. In L. G. Arango \& P. Molinier (Comp.), El trabajo y la ética del cuidado (pp. 135-156). Medellín, Colombia: La Carreta Editores.

Puig, M. (2009). Touching technologies, touching visions. The reclaiming of sensorial experience and the politics of speculative thinking. Subjectivity, 28(1), 297-315. http://dx.doi.org/10.1057/sub.2009.17

Puig, M. (2010). Ethical doings in naturecultures. Ethics, Place \& Environment, 13(2), 151-169. http://dx.doi.org/10.1080/13668791003778834

Puig, M. (2011). Matters of care in technoscience: Assembling neglected things. Social Studies of Science, 41(1), 85-106. http://dx.doi.org/10.1177/0306312710380301

Puig, M. (2012). 'Nothing Comes without Its World': Thinking with care. The Sociological Review, 60(2), 197-216. http://dx.doi.org/10.1111/j.1467954X.2012.02070.x

Revista Credencial (2011). Los personajes más soprendentes del 2011. Revista Credencial. Retrieved from http://www.revistacredencial.com/credencial/ content/los-personajes-m-s-sorprendentes-de-2011-investigaci-n

Rhoton, L. (2011). Distancing as a gendered barrier. Understanding women scientists' gender practices. Gender \& Society, 25(6), 696-716.

Roghgarden, J. (2004). Evolution's rainbow: Diversity, gender, and sexuality in nature and people. California: University of Berkley.

Ruiz, C. (2011, February 3). La Estrafalaria. El Espectador. Retrieved from http:/ / www.elespectador.com/impreso/especiales/articulo-314798-estrafalaria

Secretaría Distrital de Planeación (2010). Boletín No . 25 lesbianas, gays, bisexuales y transgeneristas en cifras. Bogotá: Secretaría Distrital de Planeación.

Semana (2010, May). Un Hombre llamado Brigitte. Semana.com. Retrieved from http://www.semana.com/gente/articulo/un-hombre-llamadobrigitte/117271-3 
Sevenhuijsen, S. (2003). The place of care. The relevance of the feminist ethic of care for social policy. Feminist Theory, 4(2), 179-197.

Silva, J. (2011, January 15). 'Aún no sabemos vivir en Colombia': Brigitte Baptiste. El Tiempo. Retrieved from http://www.eltiempo.com/archivo/ documento/CMS-8785029

Singleton, V. (2011). When contexts meet: Feminism and accountability in UK cattle farming. Science, Technology \& Human Values, 37(4), 404-433. doi: http://dx.doi.org/10.1177/0162243911418536

TEDxTalks (2013). Inventing the body: Brigitte Baptiste at TEDxTeusaquillo. Colombia: TEDxTalks. Retrieved from http://www.youtube.com/ watch?v=XsZUjf9VcuA

Towle, E. B., \& Morgan, L. M. (2013). Romancing the transgender native: Rethinking the use of the 'third gender' concept. GLQ: A Journal of Lesbian and Gay Studies, 8(4), 469-497. Retrieved from: http://muse.jhu.edu/journals/ journal_of_lesbian_and_gay_studies/v008/8.4towle.html

Tronto, J. (1994). Moral boundaries: A political argument for an Ethic of Care. London, England: Routledge.

Vessuri, H., \& Canino, M. V. (2006). Igualdad entre Géneros E Indicadores de Ciencia En Iberoamérica. In R. Guber (Comp.), El Estado de la ciencia. Principales indicadores de ciencia y tecnología iberoamericanos/ interamericanos (pp. 2330). Buenos Aires, DF: GUBER, RICyT.

Virviescas, P. (2012). Brigitte LG Baptiste, La escudera de Santurbán. Las Notas de Pastor. Retrieved from http://lasnotasdepastor.blogspot.com/2012/12/ brigitte-luis-guillermo-baptiste-la.html

Westbrook, L., \& Schilt, K. (2013). Doing gender, determining gender: Transgender people, gender panics, and the maintenance of the sex/ gender/sexuality system. Gender \& Society, 28(1), 32-57. http://dx.doi. org/10.1177/0891243213503203 


\section{Cómo citar este artículo}

Pérez-Bustos, T. (2016). Embodying a caring science: An ethnographic analysis of the communicative practices of a Colombian trans-woman scientist in the media. Universitas Humanística, 82, 429-459. http://dx.doi.org/10.11144/ Javeriana.uh82.ecse 